\title{
The Effect of Fluoride on the Structure, Function and Proteome of a Renal Epithelial Cell Monolayer
}

\begin{tabular}{|r|l|}
\hline Journal: & Environmental Toxicology \\
\hline Manuscript ID & TOX-16-116.R1 \\
\hline Wiley - Manuscript type: & Research Article \\
\hline Date Submitted by the Author: & n/a \\
\hline Complete List of Authors: & $\begin{array}{l}\text { Antonio, Ligia; University of Cambridge } \\
\text { Jeggle, Pia; University of Cambridge } \\
\text { MacVinish, Lesley; University of Cambridge, Department of Pharmacology } \\
\text { Bartram, James; University of Cambridge, Department of Pharmacology } \\
\text { Miller, Henry; University of Cambridge, Department of Pharmacology } \\
\text { Jarvis, Gavin; University of Cambridge, Department of Physiology, } \\
\text { Development and Neuroscience } \\
\text { Levy, Flavia; University of Sao Paulo } \\
\text { Santesso, Mariana; University of Sao Paulo } \\
\text { Leite, Aline; University of Sao Paulo } \\
\text { Oliveira, Rodrigo; University of São Paulo, Biological Sciences } \\
\text { Buzalaf, Marília; University of São Paulo, Biological Sciences } \\
\text { Edwardson, J; University of Cambridge, Department of Pharmacology }\end{array}$ \\
\hline Keywords: & $\begin{array}{l}\text { fluoride, kidney, epithelial ion transport, atomic force microscopy, } \\
\text { proteomics }\end{array}$ \\
\hline
\end{tabular}




\title{
The Effect of Fluoride on the Structure, Function and Proteome of a Renal Epithelial Cell Monolayer
}

\author{
Ligia S Antonio, ${ }^{1}$ Pia Jeggle, ${ }^{1}$ Lesley J MacVinish, ${ }^{1}$ James C Bartram, ${ }^{1}$ Henry Miller, ${ }^{1}$ \\ Gavin E Jarvis, ${ }^{2}$ Flávia M Levy, ${ }^{3}$ Mariana R Santesso, ${ }^{3}$ Aline L Leite, ${ }^{3}$ Rodrigo C \\ Oliveira, ${ }^{3}$ Marília AR Buzalaf, ${ }^{3} \mathbf{J}$ Michael Edwardson ${ }^{1}$
}

\footnotetext{
${ }^{1}$ Department of Pharmacology, University of Cambridge, Cambridge, UK

${ }^{2}$ Department of Physiology, Development and Neuroscience, University of Cambridge, Cambridge, UK

${ }^{3}$ Department of Biological Sciences, Bauru School of Dentistry, University of São Paulo, Bauru, SP, Brazil
}

Running head: The Effect of Fluoride on a Renal Epithelial Cell Monolayer

Correspondence to: J. Michael Edwardson, Department of Pharmacology, University of Cambridge, Tennis Court Road, Cambridge CB2 1PD, UK; e-mail, jme1000@cam.ac.uk, or Marília Afonso Rabelo Buzalaf, Department of Biological Sciences, Bauru School of Dentistry, University of São Paulo, Alameda Octávio Pinheiro Brisolla, 9-75, Bauru-SP, Brazil 17012-901; e-mail: mbuzalaf@fob.usp.br 


\begin{abstract}
High concentrations of fluoride in the body may cause toxic effects. Here, we investigated the effects of fluoride on the structure, function and proteome of a cortical collecting duct epithelium in vitro. Kidney tubule cells (M-1) were chosen because the concentration of fluoride in the kidney is 4-5-fold higher than that in plasma. Mouse M-1 cell monolayers were incubated in fluoride-containing media, and the amiloride-sensitive shortcircuit current and transepithelial resistance were measured. The Young's modulus of the epithelium was determined using atomic force microscopy, and the effect of fluoride on epithelial structure was assessed using scanning and transmission electron microscopy, and immunofluorescence. Differences in the expression of membrane proteins were evaluated using proteomics and bioinformatics. Fluoride exposure reduced both transepithelial $\mathrm{Na}^{+}$ transport and resistance. The $\mathrm{IC}_{50}$ for fluoride was $\sim 300 \mu \mathrm{M}$ for both effects, and the halftimes for the decays of ion transport and resistance were $8.4 \mathrm{~h}$ and 3.6 days, respectively. Fluoride treatment did not affect the sensitivity of $\mathrm{Na}^{+}$transport to amiloride. The Young's modulus of the epithelium was also unaffected by fluoride; however, the functional effects of fluoride were accompanied by marked structural effects. Proteomic analysis revealed changes in expression of a number of proteins, and particularly mitochondrial proteins. Treatment with fluoride had profound effects on the structure, function and proteome of a model cortical collecting duct epithelium. Significantly, however, these effects were produced only at concentrations considerably higher than those likely to be encountered in vivo.
\end{abstract}

Keywords: fluoride; kidney; epithelial ion transport; atomic force microscopy; cell stiffness; proteomics 


\section{INTRODUCTION}

Dental caries is a major public health issue worldwide, with approximately $35 \%$ of the world's population currently suffering from dental caries of their permanent teeth (Vos et al., 2012). Water fluoridation has been shown to be an effective mechanism for combating caries (Parnell et al., 2009), and artificial water fluoridation is implemented in many countries, reaching $5.7 \%$ of the world's population (Cheng et al., 2007). Fluoride is also added to toothpastes, with the result that populations are exposed to fluoride both topically and systemically (Buzalaf and Whitford, 2011). Although the benefits of water fluoridation have been thoroughly demonstrated, water fluoridation has remained a controversial issue since its introduction in the 1940s (Martin, 1989), largely as a result of uncertainty about potential toxic effects. In many parts of the world the fluoride concentration in drinking water greatly exceeds the recommended concentration $\left(1 \mathrm{mg} \mathrm{L}^{-1}\right.$, equivalent to $\left.\sim 50 \mu \mathrm{M}\right)$ because of its presence in natural sources; hence, populations in these areas are at particular risk of fluoride toxicity (McDonagh et al., 2000).

Absorbed fluoride ions freely diffuse throughout the extracellular fluid, accessing almost all tissues of the body. This process is facilitated by formation of lipid-soluble hydrogen fluoride (HF), which has a million-fold greater cell membrane permeance than ionic fluoride (Gutknecht and Walter, 1981). As mentioned above, the concentration of fluoride in drinking water varies significantly; however, the concentration ratio between drinking water and plasma is fairly constant (Taves and Guy, 1979), with minor differences depending on the ionic source of fluoride (e.g. natural calcium fluoride, or artificial sodium fluoride or fluorosilic acid (Whitford et al., 2008)). Accordingly, plasma fluoride concentration is unlikely chronically to exceed $\sim 1 \mu \mathrm{M}$ in populations drinking artificially fluoridated water or $\sim 10 \mu \mathrm{M}$ for populations with the highest fluoride concentrations in drinking water. The majority of fluoride in the body is excreted through the kidneys (Buzalaf and Whitford, 
2011). The rate of fluoride excretion is highly dependent on tubular fluid $\mathrm{pH}$, which controls the equilibrium between ionic fluoride and HF in the collecting ducts (Whitford et al., 1976).

The concentration of fluoride in the lumen of the kidney tubule is unknown, but its concentration in the kidney as a whole is significantly (4-5-fold) higher than that in plasma (Whitford et al., 1979). Hence, it would be expected that fluoride toxicity might become apparent in the kidney before other tissues. Consistent with this suggestion, several studies have indicated toxic effects on the kidneys, in particular with the acute high doses associated with the use of fluorinated general anaesthetics, both on cortical collecting duct cells in vitro (Cittanova et al., 1996) and on kidney function in vivo (Mazze et al., 1977). Nephrotoxic effects caused by chronic exposure to relatively low doses of fluoride have also been reported for the rodent proximal convoluted tubule in vivo, where cytotoxicity was evident from biomarkers of renal damage in urine and histological analysis of the tubule (Chattopadhyay et al., 2011; Cardenas-Gonzalez et al., 2013). Analysis of the renal proteome of fluoride-treated rats has detected changes in expression of genes involved in functions such as metabolism and extracellular matrix remodelling, along with other cellular processes (Carvalho et al., 2013). As a result of these multiple effects of fluoride, it is difficult to formulate a clear mechanistic explanation of fluoride toxicity. The concentrations of fluoride required to produce toxicity, and importantly whether such concentrations are reached in vivo, are also unclear.

Here, we applied a range of analytical approaches to study the effects of fluoride on the structure and function of a model cortical collecting duct cell line, the mouse M-1 line. This cell line was established from normal renal tissue, acquired from a mouse that was transgenic for the early region of Simian virus 40, rendering the cells immortal. M-1 cells retain many characteristics of cortical collecting duct cells; for instance, in culture they behave like microdissected cortical collecting duct tissue with regard to transepithelial electrical activity (Stoos 
et al., 1991). In vivo, the cortical collecting duct, along with the late distal convoluted tubule and the connecting tubule, is part of the aldosterone-sensitive distal nephron (Staruschenko, 2012). This region is able to adjust $\mathrm{Na}^{+}$intake and excretion (Loffing and Korbmacher, 2009), and is under the regulation of multiple factors, including aldosterone and vasopressin (Stockand, 2010). Even though the aldosterone-sensitive distal nephron absorbs less than $10 \%$ of the filtered $\mathrm{Na}^{+}$, its sensitivity to hormones and other factors means that it is vital in controlling the final level of $\mathrm{Na}^{+}$present in the urine. The aldosterone-sensitive distal nephron is also responsible for increasing the fractional osmolality of urea in the tubular fluid, an essential process for the production of highly concentrated urine in the medullary collecting duct (Kokko, 1987). The ability to concentrate urine is crucial to the control of total body fluid osmolality and volume homeostasis in mammals. Any toxic effect of fluoride on the function of the cortical collecting duct would therefore have major consequences for the organism as a whole.

\section{MATERIALS AND METHODS}

\section{Cell Culture}

M-1 mouse kidney cortical collecting duct cells (ATCC-CRL-2038, American Type Culture Collection, Rockville, MD, USA) were cultured in a 1:1 mixture of Dulbecco's Modified Eagle's Medium and Ham's F12 medium (Life Technologies), containing 10\% fetal bovine serum, $1 \%$ penicillin, $1 \%$ streptomycin and $5 \mu \mathrm{M}$ dexamethasone at $37^{\circ} \mathrm{C}$ in an atmosphere of $5 \% \mathrm{CO}_{2} / 95 \%$ air. For polarized monolayer formation, cells were seeded into Snapwell ${ }^{\mathrm{TM}}$ inserts (Corning), which contained a 12-mm diameter polycarbonate membrane with $0.4-\mu \mathrm{m}$ diameter pores. Inserts were placed in 6-well plates with $1.5 \mathrm{ml}$ and $4 \mathrm{ml}$ of medium on the apical and basolateral sides of the monolayers, respectively. Cells were normally cultured for 
15 days to allow the formation of a tight, polarized epithelium. Monolayers were treated with fluoride (as $\mathrm{NaF}$ ) at various concentrations and for various times prior to subsequent analysis. Note that because of the very low solubility of calcium fluoride, the concentrations of ionic calcium and fluoride in the media will be lower than the total concentrations. The program Phreeq Interactive (http://wwwbrr.cr.usgs.gov/projects/GWC coupled/phreeqc/) indicates that at $0.1 \mathrm{mM}$ and $1 \mathrm{mM} \mathrm{NaF}$, the ionic calcium and fluoride concentrations will be $20-25 \%$ and $5-10 \%$, respectively, lower than the total concentrations. The same considerations apply to the Krebs-Henseleit solution used in the measurement of transepithelial ion transport and resistance (see below).

\section{Measurement of Transepithelial Ion Transport and Resistance}

Voltage clamps (DVC-1000 Epithelial Voltage/Current Clamp, World Precision Instruments) were calibrated before each experiment (Input/Offset and Fluid RES compensation set to 0.0). Snapwell ${ }^{\mathrm{TM}}$ inserts with confluent cell monolayers were transferred to Ussing chambers

with a $1.13 \mathrm{~cm}^{2}$ aperture (World Precision Instruments). The monolayers were bathed on both apical and basolateral sides with $20 \mathrm{~mL}$ of Krebs-Henseleit solution $(117 \mathrm{mM} \mathrm{NaCl}, 4.7 \mathrm{mM}$ $\mathrm{KCl}, 2.5 \mathrm{mM} \mathrm{CaCl}_{2}, 1.2 \mathrm{mM} \mathrm{MgSO}_{4}, 1.2 \mathrm{mM} \mathrm{KH}_{2} \mathrm{PO}_{4}, 24.8 \mathrm{mM} \mathrm{NaHCO}_{3}, 11.1 \mathrm{mM}$ glucose, $\mathrm{pH} 7.4$ ) at $37^{\circ} \mathrm{C}$, with continuous aeration with $5 \% \mathrm{CO}_{2} / 95 \% \mathrm{O}_{2}$. Chambers were left for 10-30 min to equilibrate once voltage clamping had begun. PowerLab 2/25 software (ADInstruments) was used to record the short-circuit current $\left(\mathrm{I}_{\mathrm{sc}}\right)$ across the epithelium, with one data point per second plotted on continuous axes of $\mathrm{I}_{\mathrm{sc}}$ versus time. All traces were recorded using PowerLab hardware with LabChart software, and data were analysed using Microsoft Excel software. Transepithelial resistance $\left(\mathrm{R}_{\mathrm{t}}\right)$ was measured through changes in $\mathrm{I}_{\mathrm{sc}}$ during 5-s pulses to a 2-mV transepithelial voltage every $30 \mathrm{~s}$, according to Ohm's law. Amiloride hydrochloride hydrate was from Sigma. Total amiloride-sensitive current was 
measured as the change in $\mathrm{I}_{\mathrm{sc}}$ immediately following apical administration of $100 \mu \mathrm{M}$ amiloride. Concentration-response relationships for amiloride were constructed by periodic (every $150 \mathrm{~s}$ ) apical administration of sequentially increasing concentrations.

\section{Data Analysis}

Concentration-response data were fitted to the following 4-parameter logistic equation:

where $E$ is the response, $E=\frac{\operatorname{Min}-\operatorname{Max}}{\left(1+\left([I] / 10^{p I C_{50}}\right)^{n_{H}}\right)}+\operatorname{Max} \quad[I]$ is the molar concentration of
the inhibitor (e.g. amiloride or
sodium fluoride, NaF), Min is the response when $[I]=0, \operatorname{Max}$ is the response when $[I]=\infty, I C_{50}$ is the molar concentration of $I$ at which $E=(\operatorname{Min}+\operatorname{Max}) / 2$, and $n_{H}$ is the Hill coefficient.

Time-dependent changes in response were fitted to the following exponential model:

$$
E_{t}=E_{0} e^{-k t}+E_{\text {lim }}\left(1-e^{-k t}\right)
$$

where $E$ is the response, $t$ is the incubation time, $E_{0}$ is the response when $t=0, E_{\text {lim }}$ is the response at the limit of the time-dependent effect, and $k$ is the rate constant.

Residual error was modelled as follows:

$$
R U V_{i}=\alpha^{2} \hat{y}_{i}^{\gamma}
$$

where $R U V_{i}$ is the residual unexplained variance for data point $I, \alpha^{2}$ is a variance parameter, and $\hat{y}_{i}$ is the modelled response for data point $i . \gamma$ defines the relationship between residual error and response; e.g. when $\gamma=0$, residual error is constant (i.e. homoscedastic) and when $\gamma$ $=2$, the standard deviation of the residual error is directly proportional to the response (i.e. the coefficient of variation is a constant).

Data were fitted with maximum likelihood using MS Excel $2010^{\circledR}$ and NONMEM ${ }^{\circledR}$ (Icon PLC, Dublin). Parameter estimates are reported with standard error values or 95\% confidence intervals. Hypothesis tests of model parameters were carried out by applying 
constraints and performing a likelihood ratio test (LRT) on output from constrained and unconstrained models.

Where appropriate, either unpaired two-tailed Student's $t$-tests or one-way ANOVA were used to compare datasets.

\section{Young's Modulus Measurements}

The Young's modulus of living M-1 epithelial cell monolayers was determined using an atomic force microscopy (AFM) nano-indentation technique (Heinz and Hoh, 1999; Kasas and Dietler, 2008). Measurements were conducted at room temperature using a scanning probe microscope (BioScope ${ }^{\circledR}$ I SPM, Bruker) integrated into an inverted microscope (Axiovert 135, Zeiss). Cell monolayers were washed with 4-(2-hydroxyethyl)-1piperazineethanesulfonic acid- (HEPES)-buffered solution (135 mM NaCl, $5 \mathrm{mM} \mathrm{KCl}, 1 \mathrm{mM}$ $\mathrm{MgCl}_{2}, 1 \mathrm{mM} \mathrm{CaCl} 2,10 \mathrm{mM}$ HEPES, $\mathrm{pH}$ 7.4) and bathed in the same solution during experiments. Measurements were performed using soft cantilevers (spring constant, $<20$ $\mathrm{pN} / \mathrm{nm}$; Novascan) with a polystyrene sphere (diameter, $10 \mu \mathrm{m}$ ) as the tip. A maximal loading force of $10 \mathrm{nN}$ was applied. AFM data were collected with NanoScope software 5.31 (Bruker). Young's modulus values were calculated from force-distance curves using AtomicJ Software (Hermanowicz et al., 2014). An average of eight measurements were made for each cell, and the mean values calculated for each cell.

\section{Scanning Electron Microscopy (SEM)}

Cell monolayers on polycarbonate membranes (excised from Snapwell ${ }^{\mathrm{TM}}$ inserts) and supported on coverslips were quench-frozen by plunging, cell face first, into melting propane cooled in liquid nitrogen. Monolayers were freeze-dried in a modified Edwards 306 Auto 306 carbon coating unit (Warley and Skepper, 2000). After drying, the cells were coated with 
carbon and attached to SEM stubs with colloidal silver. The cells were coated with $10 \mathrm{~nm}$ of gold in a Quorum/Emitech K575X sputter coater and viewed in an FEL-Philips XL30 FEGSEM at $5 \mathrm{kV}$.

\section{Transmission Electron Microscopy (TEM)}

Cell monolayers were fixed in $2 \%$ glutaraldehyde and $2 \%$ formaldehyde in $0.05 \mathrm{M}$

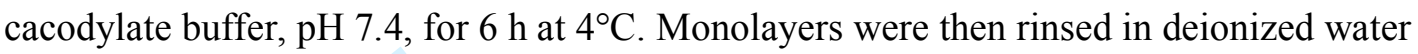
and treated with $1 \%$ osmium ferricyanide for $2 \mathrm{~h}$ at room temperature. Monolayers were rinsed in deionized water and treated with $2 \%$ uranyl acetate in $0.05 \mathrm{M}$ maleate buffer at $\mathrm{pH}$ 5.5 for $18 \mathrm{~h}$ at room temperature. They were again rinsed in deionized water and dehydrated in an ascending series of ethanol solutions from $70 \%$ to $100 \%$, followed by treatment with 2 changes of dry acetonitrile and infiltration with Quetol epoxy resin. Images were captured in an FEI Tecnai G2 electron microscope operated at $120 \mathrm{kV}$, using an AMT XR60B digital camera running Deben software.

\section{Immunofluorescence}

Cell monolayers were fixed in 4\% paraformaldehyde in phosphate-buffered saline (PBS), and permeabilized by treatment with $0.05 \%$ saponin in PBS containing $0.2 \%$ gelatin. Monolayers were incubated in permeabilization buffer containing rat monoclonal anti-zona occludens (ZO-1) monoclonal antibody (eBioscience), followed by fluorescein isothiocyanateconjugated rabbit anti-rat secondary antibody (Sigma). Cells were imaged by confocal laser scanning microscopy.

\section{Proteomic Analysis}


Cell monolayers were either untreated (control), or exposed to $1 \mathrm{mM}$ fluoride (as $\mathrm{NaF}$ ) for either $24 \mathrm{~h}$ or $96 \mathrm{~h}$. Experiments were done in quintuplicate. Membrane proteins were extracted using a Mem-PER ${ }^{\mathrm{TM}}$ eukaryotic membrane protein extraction kit (Thermo Scientific). Fractions containing hydrophobic proteins were collected and purified using detergent removal spin columns (Thermo Scientific). To each sample (50 $\mu \mathrm{g}$ in a volume of $50 \mu \mathrm{l})$, the following additions were made: $10 \mu \mathrm{l}$ of $50 \mathrm{mM}$ ammonium bicarbonate; $25 \mu \mathrm{l}$ of $0.2 \%$ RapiGEST ${ }^{\mathrm{TM}}$ (Waters) followed by incubation for $15 \mathrm{~min}$ at $37^{\circ} \mathrm{C} ; 2.5 \mu 1$ of $100 \mathrm{mM}$ dithiothreitol followed by incubation for $30 \mathrm{~min}$ at $37^{\circ} \mathrm{C} ; 2.5 \mu \mathrm{l}$ of $300 \mathrm{mM}$ iodoacetamide followed by incubation for $30 \mathrm{~min}$ at room temperature (in the dark); $10 \mu \mathrm{l}$ of trypsin (100 ng; Trypsin Gold Mass Spectrometry, Promega) followed by digestion for $14 \mathrm{~h}$ at $37^{\circ} \mathrm{C}$. After digestion, $10 \mu \mathrm{l}$ of $5 \%$ trifluoroacetic acid was added. The sample was then incubated for 90 $\min$ at $37^{\circ} \mathrm{C}$ and centrifuged at $14,000 \mathrm{rpm}$ for $30 \mathrm{~min}$. The supernatant was collected and 5 $\mu 1$ of alcohol dehydrogenase $\left(1 \mathrm{pmol} \mu \mathrm{L}^{-1}\right)$ plus $85 \mu$ of $0.1 \%$ formic acid in $3 \%$ acetonitrile were added.

Identification of peptides was performed on a nanoAcquity UPLC-XEVO QToF mass spectometry system (Waters), as previously described (Lima Leite et al., 2014). Difference in expression between groups was determined using PLGS software and expressed as $\mathrm{P}<0.05$ for down-regulated and $\mathrm{P}>0.95$ for up-regulated proteins. Functional enrichment was performed with ClueGo, a Cytoscape plugin. Bioinformatics analysis was performed for each comparison, as described previously (Lima Leite et al., 2014; Bauer-Mehren, 2013; Millan, 2013; Orchard, 2012).

\section{RESULTS}

Fluoride does not Acutely Affect Transepithelial Ion Transport or Resistance 
Cells were cultured for 15 days on polycarbonate membranes to produce polarized monolayers, and transepithelial ion transport was measured using short circuit current $\left(\mathrm{I}_{\mathrm{sc}}\right)$ recordings in Ussing chambers. Monolayers (transporting area, $1.13 \mathrm{~cm}^{2}$ ) typically produced an $\mathrm{I}_{\mathrm{sc}}$ of around $12 \mu \mathrm{A}$ and a transepithelial resistance $\left(\mathrm{R}_{\mathrm{t}}\right)$ of $1300 \Omega$ (Fig. 1A). Addition of amiloride $(100 \mu \mathrm{M})$ caused a rapid and maintained reduction in $\mathrm{I}_{\mathrm{sc}}$ by $>90 \%$, indicating that $\mathrm{Na}^{+}$transport via epithelial $\mathrm{Na}^{+}$channels (ENaCs) was the major contributor to the $\mathrm{I}_{\mathrm{sc}}$. This finding was expected since $\mathrm{Na}^{+}$reabsorption in the cortical collecting duct primarily involves apical transport through $\mathrm{ENaC}$ driven by the activity of basolateral $\mathrm{Na}^{+} / \mathrm{K}^{+}$ATPase (Staruschenko, 2012). Acute addition of fluoride $(1 \mathrm{mM})$ produced no detectable change in either $\mathrm{I}_{\mathrm{sc}}$ or $\mathrm{R}_{\mathrm{t}}$ (Fig. 1B). Furthermore, there was no relationship between fluoride concentration and either $\mathrm{I}_{\mathrm{sc}}(\mathrm{P}=0.79, \mathrm{n}=36$; Fig. 1C $)$ or $\mathrm{R}_{\mathrm{t}}(\mathrm{P}=0.48, \mathrm{n}=36$; Fig. 1D). Note that these results indicate that the small reduction in ionic calcium concentration caused by fluoride addition (see above) had no effect on tight junction integrity.

\section{Pre-treatment with Fluoride Reduces Transepithelial Ion Transport and Resistance in a Concentration-dependent Manner}

Next, we incubated monolayers with fluoride for $96 \mathrm{~h}$ before measuring $\mathrm{I}_{\mathrm{sc}}$ and $\mathrm{R}_{\mathrm{t}}$. As shown in Fig. 2A, control monolayers showed very similar $\mathrm{I}_{\mathrm{sc}}, \mathrm{R}_{\mathrm{t}}$ and responses to amiloride as before (Fig. 1A). In contrast, monolayers that had been treated with $700 \mu \mathrm{M}$ fluoride had a greatly reduced $\mathrm{I}_{\mathrm{sc}}$, and $\mathrm{R}_{\mathrm{t}}$ (Fig. $2 \mathrm{~B}$ ). The concentration dependence of the effects of fluoride on $\mathrm{I}_{\mathrm{sc}}$ is shown in Fig. 2C. Amiloride-sensitive $\mathrm{I}_{\mathrm{sc}}$ was reduced by treatment with fluoride from $10.4 \pm 0.9$ (SEM) $\mu \mathrm{A} \mathrm{cm}^{-2}$ to $0.1 \pm 0.3 \mu \mathrm{A} \mathrm{cm}^{-2}(\mathrm{n}=66)$; the $\mathrm{pIC}_{50}$ for fluoride (M) was $3.51 \pm 0.05$, and $n_{H}$ was $5.46 \pm 1.76$. The concentration dependence of the effects of fluoride on $R_{t}$ is shown in Fig. 2D. $R_{t}$ was reduced from $1229 \pm 125 \Omega \mathrm{cm}^{2}$ to $14 \pm 12 \Omega \mathrm{cm}^{2}(\mathrm{n}=66)$; the $\mathrm{pIC}_{50}$ for $\mathrm{NaF}(\mathrm{M})$ was $3.43 \pm 0.04$, and $\mathrm{n}_{\mathrm{H}}$ was $3.69 \pm 0.52$. 


\section{The Effects of Fluoride on Transepithelial Ion Transport and Resistance Occur over Different Time-courses}

Measurements of the $I_{s c}$ and $R_{t}$ values were made for monolayers treated with $400 \mu \mathrm{M} \mathrm{NaF}$ for various times. An exponential decay model was generated in order to compare the time dependence of the effects of fluoride on the two parameters. The calculated rate constant for the effect of $\mathrm{NaF}$ on $\mathrm{I}_{\mathrm{sc}}$ was $0.083 \pm 0.006 \mathrm{~h}^{-1}$, and the minimum value of $\mathrm{I}_{\mathrm{sc}}$ was $0.1 \pm 0.4 \mu \mathrm{A}$ $\mathrm{cm}^{-2}\left(\mathrm{n}=43\right.$; closed symbols, Fig. 3A). The rate constant for the effect on $\mathrm{R}_{\mathrm{t}}$ was $0.19 \pm 0.02$ day $^{-1}$, with a plateau value constrained to zero (Fig. 3B). The half-times of decay of $I_{s c}$ and $R_{t}$ were therefore $8.4 \mathrm{~h}(95 \%$ confidence interval, $7.3-9.9 \mathrm{~h})$ and 3.1 days $(95 \%$ confidence interval, 2.9-4.9 days), respectively. As shown by the open symbols in Figures 3A and 3B, there was no effect of incubation time on either $I_{s c}$ or $R_{t}$ in the absence of fluoride.

Low-magnification brightfield micrographs were taken of control monolayers and monolayers growing on impermeable plastic supports and treated with either $10 \mu \mathrm{M}$ or $1 \mathrm{mM}$ fluoride for $72 \mathrm{~h}$. Representative micrographs are shown in Figure 4. The control monolayer shows out-of-focus areas, known as 'domes' (arrows), which are caused by the lifting of the tight monolayer from the impermeable support as a result of transport of ions and accompanying water in an apical-to-basolateral direction. The domes are also present in the monolayer that has been exposed to $10 \mu \mathrm{M}$ fluoride, consistent with the lack of significant effect of fluoride at this concentration on $\mathrm{I}_{\mathrm{sc}}$ (Fig. 2C). In contrast, domes are absent from monolayers treated with $1 \mathrm{mM}$ fluoride, a concentration that almost abolished $\mathrm{I}_{\mathrm{sc}}$ at $72 \mathrm{~h}$ (Figs. 2C and 3A).

\section{Pre-incubation with Fluoride does not Affect the Sensitivity of ENaC to Amiloride}


Concentration-response curves for inhibition of $\mathrm{I}_{\mathrm{sc}}$ by amiloride were produced for both control cells and cells pre-incubated with $400 \mu \mathrm{M} \mathrm{NaF}$ for 96 h. As shown in Fig. 5, fluoride treatment reduced the amiloride-sensitive $\mathrm{I}_{\mathrm{sc}}$ from $13.1 \pm 0.6 \mu \mathrm{A} \mathrm{cm} \mathrm{cm}^{-2}$ (dotted line, open symbols) to $1.7 \pm 0.2 \mu \mathrm{A} \mathrm{cm}^{-2}$ (solid line, closed symbols; $\mathrm{P}=0.0002$ ). However, the $\mathrm{pIC}_{50}$ value $(\mathrm{M})$ for amiloride $(7.47 \pm 0.54$ without fluoride and $7.05 \pm 0.57$ with fluoride) was not significantly affected $(\mathrm{P}=0.14 ; \mathrm{n}=36$ for both conditions $)$.

\section{Fluoride does not Affect the Young's Modulus of the Epithelial Cells}

As an indicator of the effect of fluoride on the general condition of the M-1 cells we measured their Young's modulus by nanoindentation using an atomic force microscope. Cell monolayers growing in plastic culture dishes were either incubated with $1 \mathrm{mM}$ fluoride for 96 h, a condition which reduces both $I_{s c}$ and $R_{t}$ almost to zero (Figs. 2 and 3), or left untreated. At the end of the incubation period, the mechanical properties of cells within the monolayers were measured using AFM probes with spherical tips as mechanosensors. The AFM probe was lowered onto the cell monolayer until it made contact with the apical membrane. It was then allowed to indent the cells for $\sim 300 \mathrm{~nm}$, which resulted in bending of the cantilever upon which the tip is mounted. This bending was amplified by a laser beam projected onto the back of the cantilever, and the reflected beam was monitored by a split photodiode. The tip was retracted from the cell, and multiple cycles of indentation and retraction were carried out. A force-distance curve was plotted for each cycle, relating the bending of the cantilever (or the applied force) to the position of the sample. The Young's modulus of each cell was then calculated from the slope of this curve. The values of Young's modulus for control and fluoride-treated cells were $1.008 \pm 0.062(\mathrm{n}=85$ cells $)$ and $0.988 \pm 0.066(\mathrm{n}=78$ cells $) \mathrm{kPa}$, respectively ( $\mathrm{P}=0.825$, one-way ANOVA). Hence, fluoride treatment had no significant effect 
on the Young's modulus of the cells, indicating that there was no fluoride-induced change in their stiffness.

\section{Fluoride Perturbs the Structure of the Epithelial Monolayer}

To probe the fine structure of the M-1 cell monolayer, we first turned to scanning electron microscopy. Confluent monolayers were either untreated or treated for $96 \mathrm{~h}$ with $1 \mathrm{mM}$ fluoride. Typical scanning election micrographs are show in Fig. 6A. As can be seen, the apical surface of the control monolayer was almost flat, although individual cells were visible. In contrast, individual cells in the fluoride-treated monolayer had a dome-shaped appearance. The appearance of the fluoride-treated monolayers suggested that the cells within the monolayer may have become at least partially separated from each other, perhaps because of a breakdown of the tight junctions between them. TEM of vertical sections through the monolayer (Fig. 6B) revealed apparently intact tight junctions in both control and fluoridetreated cells (indicated by the arrows). However, when the distribution of the tight junction protein zona occludens (ZO-1) was probed by immunofluorescence, a clear difference was seen (Fig. 7). Specifically, the control monolayer had a pavement like appearance, with a polygonal distribution of staining for ZO-1. In contrast, the fluoride-treated monolayer showed a broken pattern of staining, indicating a breakdown of the normal tight junction structure at many sites in the epithelium. Arrows indicate ZO-1 staining that was not part of a complete polygon.

\section{Proteomic Analysis}

Proteomic analysis identified a total of 356 and 229 proteins for cells treated with $1 \mathrm{mM}$ fluoride for 24 and 96 h, respectively. For the 24-h samples, comparative analysis showed 39 and 73 proteins down- and up-regulated, respectively, in the fluoride-treated group compared 
with control (Table SI). The numbers of exclusive proteins in the control and fluoride-treated groups were 175 (Table SII) and 28 (Table SIII) proteins, respectively. GO analysis showed that the majority of proteins with altered expression were related to the 'mitochondrion' term, with a $45.2 \%$ frequency. In addition, 63 proteins were related to the 'organelle membrane' term, corresponding to organelle outer membrane (3.4\%), nuclear membrane $(3.4 \%)$ and mitochondrial inner membrane (17\%) terms. Exposure to fluoride increased the expression of different isoforms of tubulin, 14-3-3 protein, annexin, and isoforms of histone and Rasrelated proteins. On the other hand, various isoforms of ATP synthase, ADP/ATP translocase, actin and cytochrome proteins were reduced upon exposure to fluoride. Fig. 8 shows the complex sub-network generated by JActiveModules for the comparison between control and fluoride-treated group. In the centre of the network are two isoforms of 14-3-3 protein, which were increased upon exposure to fluoride and which are involved in the regulation of a large spectrum of signalling pathways. Among the interacting proteins present in the centre of the subnetwork are isoforms of 3 beta-hydroxysteroid dehydrogenase (involved in the biosynthesis of hormonal steroids and also in cell signaling). Three proteins exclusively identified in the fluoride-treated group can be seen in the interaction network, of which two are involved in protein synthesis (non-POU domain-containing octamer-binding protein, involved in transcriptional regulation, and ELAV-like protein 1, involved in the stabilization of mRNA). The other protein (the mitochondrial import inner membrane translocase subunit, Tim 13) is a mitochondrial intermembrane chaperone that participates in the import and insertion of multi-pass transmembrane proteins into the mitochondrial inner membrane.

For the 96-h samples, comparative analysis showed 13 and 22 proteins down- and upregulated, respectively (Table SIV). The numbers of exclusive proteins in the control and fluoride-treated groups were 46 (Table SV) and 12 (Table SVI), respectively. GO analysis showed that the majority of proteins with altered expression were related to the 
'mitochondrion' term, with a $46 \%$ frequency. In addition, $38 \%$ were related to 'intermediate filament', $20 \%$ to 'blood microparticle' and $7 \%$ to 'endoplasmic reticulum-Golgi intermediate compartment' terms. Different isoforms of Ras-related proteins, as well as proteins and enzymes involved in energy production, such as mitochondrial glyceraldehyde3-phosphate dehydrogenase, malate dehydrogenase, citrate synthase, ATP synthase subunit alpha, ATP synthase subunit beta, cytochrome b-c 1 complex subunit 6, and cytochrome c oxidase subunit 5A, were increased by fluoride, as well as proteins involved in the unfolded protein response, such as calnexin and $60-\mathrm{kDa}$ heat shock protein, and in the maintenance of cellular organelles, such as stomatin-like protein 2 and surfeit locus protein 4. Exposure to fluoride reduced the expression of isoforms of actin and of proteins involved in membrane transport, such as extended synaptotagmin-1 and protein Mal2. Notably, different isoforms of heterogeneous nuclear ribonucleoproteins (involved in mRNA stabilization and splicing) were absent when cells were exposed to fluoride. Fig. 9 shows the sub-network generated by JActiveModules for the comparison between control and fluoride-treated groups. The proteins with altered expression interacted with 14-3-3 protein zeta/delta and eta, 3phosphoinositide-dependent protein kinase 1 (a master kinase), 6-phosphogluconolactonase (a component of the pentose phosphate pathway), high mobility group protein HMGI-C (a transcriptional regulator), $\mathrm{Ca}^{2+}$-activated $\mathrm{K}^{+}$channel subunit alpha-1, IQ calmodulin-binding motif-containing protein 1 (involved in ciliogenesis) and nephrocystin-4 (involved in organization of the apical junctions). Some proteins that interacted with HMGI-C, such as heterogeneous nuclear ribonucleoprotein $\mathrm{U}$ (involved in mRNA stabilization) and guanine nucleotide-binding protein $\mathrm{G}(\mathrm{s})$ subunit alpha isoforms XLas (a signal transducer) were present only in the control group, while leucine-rich repeat-containing protein 59 (required for nuclear import of FGF1) was up-regulated in the fluoride-treated group. This protein also interacted with 14-3-3 protein zeta/delta, which, in turn, interacted with many proteins found 
exclusively in the control group, such as malectin (involved in protein N-glycosylation), short-chain specific acyl-CoA dehydrogenase (mitochondrial), hydroxyacyl-coenzyme A dehydrogenase (mitochondrial; involved in fatty acid beta-oxidation) and NADH dehydrogenase [ubiquinone] iron-sulfur protein 3 (a component of the mitochondrial respiratory chain - complex I), heterogeneous nuclear ribonucleoprotein K (involved in mRNA stabilization), sulphotransferase family cytosolic 1B member 1 (which sulphonates compounds, such as hormones, neurotransmitters, drugs and xenobiotics, increasing their solubility and renal excretion), guanine nucleotide-binding protein $\mathrm{G}(\mathrm{s})$ subunit alpha isoforms short, peptidyl-prolyl cis-trans isomerase A (involved in protein folding), keratin, type I cytoskeletal 18 (involved in filament reorganization), radixin and moesin (which connect cytoskeletal structures to the plasma membrane). On the other hand, some proteins that interacted with 14-3-3 protein zeta/delta were increased upon exposure to fluoride. These proteins are mainly involved in energy metabolism, such as the mitochondrial enzymes citrate synthase, malate dehydrogenase (a component of the Krebs cycle) and ATP synthase subunit beta, as well as glyceraldehyde-3-phosphate dehydrogenase (involved in glycolysis and nuclear events, such as transcription, RNA transport, DNA replication and apoptosis), and calnexin. In addition, annexin 5 interacted with $\mathrm{Ca}^{2+}$-activated $\mathrm{K}^{+}$channel subunit alpha1.

\section{DISCUSSION}

We have investigated the effects of fluoride on a number of properties of M-1 cell cortical collecting duct monolayers. Collecting duct cells were chosen because the kidney experiences particularly high fluoride concentrations (4-5-fold higher than plasma concentrations) during fluoride exposure. We found that electrogenic ion transport in M-1 cell epithelia consisted almost entirely of $\mathrm{Na}^{+}$transport through $\mathrm{ENaC}$ channels in the apical membrane of the 
epithelium, as judged by the sensitivity of the short-circuit current to amiloride. Fluoride (1 $\mathrm{mM}$ ) had no detectable effect on ion transport when added acutely to the epithelia. In contrast, longer-term fluoride exposure reduced both epithelial ion transport and transepithelial resistance. $\mathrm{Th} \mathrm{IC}_{50}$ value for fluoride for both effects was $\sim 300 \mu \mathrm{M}$, and the half-times for the decays of ion transport and resistance (at $400 \mu \mathrm{M}$ fluoride) were $8.4 \mathrm{~h}$ and 3.6 days, respectively. Fluoride treatment $(400 \mu \mathrm{M})$ did not affect the sensitivity of the transepithelial $\mathrm{Na}^{+}$transport to amiloride, ruling out a direct effect of fluoride on $\mathrm{ENaC}$.

Several previous studies have indicated that fluoride has a concentration-dependent cytotoxic effect. For instance, significant cell death (37\%) was observed in ameloblast-like LS8 cells treated for $72 \mathrm{~h}$ with $1 \mathrm{mM}$ fluoride, the highest concentration used in our study (Yang et al., 2013). Fluoride has also been shown to cause apoptosis in osteosarcoma UMR 106 cells (Hirano and Ando, 1997). Specifically, treatment for 72 hours with $1 \mathrm{mM}$ fluoride led to approximately $4 \%$ cell death in a low-density cell culture and approximately $20 \%$ cell death in a high-density cell culture. We applied several techniques to look for fluorideinduced changes in the properties of M-1 epithelia that might correlate with, and perhaps explain, the observed functional deficits. Somewhat to our surprise, we found no change in the Young's modulus of the epithelium, indicating that the stiffness of the cells was unaffected by fluoride, even at a concentration $(1 \mathrm{mM})$ that caused profound functional effects. However, after 96 hours of fluoride treatment, the cells became more dome-shaped, as viewed by SEM, suggesting that the epithelial integrity might be compromised, causing an increase in leakiness, which would in turn lead to the observed reduction in resistance. Tight junctions could still be observed by TEM after fluoride treatment, but the distribution of the tight junction marker ZO-1 became disorganized, again indicating a loss of epithelial integrity. 
Our proteomics/bioinformatics analysis detected changes in the expression of many proteins in response to fluoride $(1 \mathrm{mM})$. Mitochondrial proteins were particularly affected, both at 24 hours and at 96 hours, and expression levels of proteins involved in intracellular trafficking, the cytoskeleton, and the response to stress were also changed. The effect on cytoskeletal proteins is interesting given the lack of effect of fluoride on cell stiffness. Effects of fluoride on mitochondrial structure, including crystal formation, have been reported previously, albeit at $1 \mathrm{mM}$ and above (Cittanova et al., 1996). In vivo experiments with rats have shown that exposure to high doses of fluoride via drinking water increased volume density of mitochondria (Ribeiro et al., 2006), altered the expression of several mitochondrial enzymes (Pereira et al., 2013; Chauhan et al., 2013), caused oxidative damage to mitochondria (Anuradha et al., 2001) and reduced ATP synthesis (Barbier et al., 2010; Sun et al., 2015). We suggest that deleterious effects on mitochondrial function are likely to be involved in the observed reduction in transepithelial $\mathrm{Na}^{+}$transport.

Our results reveal that neither transepithelial $\mathrm{Na}^{+}$transport nor resistance is affected until the fluoride concentration reaches around $100 \mu \mathrm{M}$, at least over a 96-h incubation period. Whether these effects are physiologically relevant will depend upon whether (1) results with mouse M-1 cell monolayers can be translated to humans, (2) these concentrations are ever reached in the human kidney, and (3) longer-term exposure to fluoride might cause more severe toxic effects. The highest plasma concentration that the human kidney is likely to encounter is during use of fluorinated general anaesthetics, such as sevoflurane. During anaesthesia, plasma fluoride concentrations rise to between 20 and $50 \mu \mathrm{M}$, with little sign of profound effects on renal function (Smith et al., 1996). This finding is consistent with the 'threshold' concentration of $\sim 100 \mu \mathrm{M}$ that we report here, suggesting that the response of mouse M-1 cells to fluoride may indeed be translatable to man. Of course, exposure to sevoflurane would typically occur for only 1-2 hours during a surgical procedure, a very 
different situation from lifelong exposure to fluoride in drinking water. In a community with water fluoridated at the World Health Organization's recommended maximum concentration of $1 \mathrm{mg} / \mathrm{L}$, ionic plasma fluoride concentration averaged only $3.89 \mu \mathrm{M}$ in the over-60s (the age group with the highest mean ionic plasma concentration, because of declining renal function; Singer and Ophaug, 1979). Even in communities where water fluoride was 5.6 $\mathrm{mg} / \mathrm{L}$, far exceeding the recommended concentration, mean ionic plasma fluoride still only reached $4.3 \mu \mathrm{M}$ (Guy et al., 1976). We therefore suggest that it is highly unlikely that water fluoridation would have a detrimental effect on renal function, even during long-term exposure.

In conclusion, our results show that fluoride exposure can induce changes in kidney cell structure and function but only at concentrations higher than those likely to be encountered under normal circumstances. Our study thereby reinforces the safety of controlled artificial water fluoridation.

Acknowledgements: We are grateful to Dr. Jeremy Skepper of the Cambridge Advanced Imaging Centre for his expert assistance with the scanning and transmission electron microscopy. This work was supported by a grant from the CAPES Science Without Borders Programme (Brazil). L.S.A was supported by the CAPES Visiting Scholar Programme. P.J. and J.M.E. were supported by Kidney Research UK.

\section{REFERENCES}

Anuradha CD, Kanno S, Hirano S. 2001. Oxidative damage to mitochondria is a preliminary step to caspase-3 activation in fluoride-induced apoptosis in HL-60 cells. Free Radic Biol Med 31:367-373.

Barbier O, Arreola-Mendoza L, Del Razo LM. 2010. Molecular mechanisms of fluoride toxicity. Chem Biol Interact 188:319-333. 
Baur-Mehren A. 2013. Integration of genomic information with biological networks using Cytoscape. Meth Mol Biol 1021:37-61.

Buzalaf MAR, Whitford GM. 2011. Fluoride metabolism. In: Buzalaf MAR (ed.) Fluoride and the Oral Environment. Monogr Oral Sci 22:20-36. Basel: Karger.

Cárdenas-González MC, Del Razo LM, Barrera-Chimal J, Jacobo-Estrada T, López-Bayghen E, Bobadilla, NA, Barbier O. 2013. Proximal renal tubular injury in rats sub-chronically exposed to low fluoride concentrations. Toxicol and Appl Pharmacol 272:888-894.

Carvalho JG, Leite AD, Peres-Buzalaf C, Salvato F, Labate CA, Everett ET, Whitford GM, Buzalaf MA. 2013. Renal proteome in mice with different susceptibilities to fluorosis. PLOS One 8:e53261.

Chattopadhyay A, Podder S, Agharwal S, Bhattacharya S. 2011. Fluoride-induced histopathology and synthesis of stress protein in liver and kidney of mice. Arch Toxicol $85: 327-335$.

Chauhan SS, Mahmood A, Ojha S. 2013. Ethanol and age enhances fluoride toxicity through oxidative stress and mitochondrial dysfunctions in rat intestine. Mol Cell Biochem $384: 251-262$

Cheng KK, Chalmers I, Sheldon TA. 2007. Adding fluoride to water supplies. Brit Med J 335:699-702.

Cittanova ML, Lelongt B, Verpont MC, Geniteau-Legendre M, Wahbe F, Prie D, Coriat P, Ronco PM. 1996. Fluoride ion toxicity in human kidney collecting duct cells. Anesthesiology 84, 428-435.

Gutknecht J, Walter A. 1981. Hydrofluoric acid and nitric-acid transport through lipid bilayer-membranes. Biochim Biophys Acta 644:153-156. 
Guy WS, Taves DR, Brey WSJ. 1976. Organic fluorocompounds in human plasma:

Prevalence and characterization. In: Filler R, editor. Biochemistry involving carbonfluorine bonds. Am Chem Soc Symp Ser. No 28, Am Chem Soc:117-134.

Heinz WF, Hoh JH. 1999. Spatially resolved force spectroscopy of biological surfaces using the atomic force microscope. Trends Biotechnol 17:143-150.

Hermanowicz P, Sarna M, Burda K, Gabrys H. 2014. AtomicJ: An open source software for analysis of force curves. Rev Sci Instrum 85:063703.

Kasas S, Dietler G. 2008. Probing nanomechanical properties from biomolecules to living cells. Pflügers Arch 456:13-27.

Kokko JP. 1987. The role of the collecting duct in urinary concentration. Kidney Int 31:606610.

Lima Leite A, Gualiume Vaz Madureira Lobo J, Barbosa da Silva Pereira HA, Silva Fernandes M, Martini T, Zucki F, Sumida DH, Rigalli A, Buzalaf MA. 2014. Proteomic analysis of gastrocnemius muscle in rats with streptozotocin-induced diabetes and chronically exposed to fluoride. PLOS One 9:e106646.

Loffing J, Korbmacher C. 2009. Regulated sodium transport in the renal connecting tubule (CNT) via the epithelial sodium channel (ENaC). Pflügers Arch 458:111-135.

Martin B. 1989. The sociology of the fluoridation controversy: a reexamination. Sociol Q 30:59-76.

Mazze RI, Calverley RK, Smith NT. 1977. Inorganic fluoride nephrotoxicity: prolonged enflurane and halothane anesthesia in volunteers. Anesthesiology 46:265-271.

McDonagh MS, Whiting PF, Wilson PM, Sutton AJ, Chestnutt I, Cooper J, Misso K, Bradley M, Treasure E, Kleijnen J. 2000. Systematic review of water fluoridation. Brit Med J $321,855-859$. 
Millan PP. 2013. Visualization and analysis of biological networks. Meth Mol Biol 1021:6388.

Orchard S. 2012. Molecular interaction databases. Proteomics 12:1656-1662.

Parnell C, Whelton H, O’Mullane D, 2009. Water fluoridation. Eur Arch Paediatr Dent Off J Eur Acad Paediatr Dent 10:141-148.

Pereira HA, Leite Ade L, Charone S, Lobo JG, Cestari TM, Peres-Buzalaf C, Buzalaf MA. 2013. Proteomic analysis of liver in rats chronically exposed to fluoride. PLOS One 8:e75343.

Ribeiro DA, Hirota L, Cestari TM, Ceolin DS, Taga R, Assis GF. 2006. Ultrastructural morphometric analysis of ameloblasts exposed to fluoride during tooth development. $\mathrm{J}$ Mol Histol 37:361-367.

Singer L, Ophaug RH. 1979. Concentrations of ionic, total, and bound fluoride in plasma. Clin Chem 25, 523-525.

Smith I, Nathanson M, White PF. 1996. Sevofluorane - a long-awaited volatile anaesthetic. Brit J Anaesth 76:435-445.

Staruschenko A. 2012. Regulation of transport in the connecting tubule and cortical collecting duct. Comp Physiol 2:1541-1584.

Stockand JD. 2010. Vasopressin regulation of renal sodium excretion. Kidney Int 78:849856.

Stoos BA, Náray-Fejes-Tóth A, Carretero OA, Ito S, Fejes-Tóth G. 1991. Characterization of a mouse cortical collecting duct cell-line. Kidney Int 39:1168-1175.

Sun Z, Zhang W, Xue X, Zhang Y, Niu R, Li X et al. 2015. Fluoride decreased the sperm ATP of mice through inhabiting mitochondrial respiration. Chemosphere 144:1012-1017.

Taves DR, Guy WS. 1979. Distribution of fluoride among body fluid compartments. Am Assoc Adv Sci, Selected Symposia Series, No. 11, 159-185. 
Vos T, Flaxman AD, Naghavi M, Lozano R, Michaud C, Ezzati M, Shibuya K, Salomon JA, Abdalla S, Aboyans V, Abraham J, Ackerman I, Aggarwal R, Ahn SY, Ali MK, Alvarado M, Anderson HR, Anderson LM, Andrews KG, Atkinson C, Baddour LM, Bahalim AN, Barker-Collo S, Barrero LH, Bartels DH, Basáñez MG, Baxter A, Bell ML, Benjamin EJ, Bennett D, Bernabé E, Bhalla K, Bhandari B, Bikbov B, Bin Abdulhak A, Birbeck G, Black JA, Blencowe H, Blore JD, Blyth F, Bolliger I, Bonaventure A, Boufous S, Bourne R, Boussinesq M, Braithwaite T, Brayne C, Bridgett L, Brooker S, Brooks P, Brugha TS, Bryan-Hancock C, Bucello C, Buchbinder R, Buckle G, Budke CM, Burch M, Burney P, Burstein R, Calabria B, Campbell B, Canter CE, Carabin H, Carapetis J, Carmona L, Cella C, Charlson F, Chen H, Cheng AT, Chou D, Chugh SS, Coffeng LE, Colan SD, Colquhoun S, Colson KE, Condon J, Connor MD, Cooper LT, Corriere M, Cortinovis M, de Vaccaro KC, Couser W, Cowie BC, Criqui MH, Cross M, Dabhadkar KC, Dahiya M, Dahodwala N, Damsere-Derry J, Danaei G, Davis A, De Leo D, Degenhardt L, Dellavalle R, Delossantos A, Denenberg J, Derrett S, Des Jarlais DC, Dharmaratne SD, Dherani M, Diaz-Torne C, Dolk H, Dorsey ER, Driscoll T, Duber H, Ebel B, Edmond K, Elbaz A, Ali SE, Erskine H, Erwin PJ, Espindola P, Ewoigbokhan SE, Farzadfar F, Feigin V, Felson DT, Ferrari A, Ferri CP, Fèvre EM, Finucane MM, Flaxman S, Flood L, Foreman K, Forouzanfar MH, Fowkes FG, Franklin R, Fransen M, Freeman MK, Gabbe BJ, Gabriel SE, Gakidou E, Ganatra HA, Garcia B, Gaspari F, Gillum RF, Gmel G, Gosselin R, Grainger R, Groeger J, Guillemin F, Gunnell D, Gupta R, Haagsma J, Hagan H, Halasa YA, Hall W, Haring D, Haro JM, Harrison JE, Havmoeller R, Hay RJ, Higashi H, Hill C, Hoen B, Hoffman H, Hotez PJ, Hoy D, Huang JJ, Ibeanusi SE, Jacobsen KH, James SL, Jarvis D, Jasrasaria R, Jayaraman S, Johns N, Jonas JB, Karthikeyan G, Kassebaum N, Kawakami N, Keren A, Khoo JP, King CH, Knowlton LM, Kobusingye O, Koranteng A, Krishnamurthi R, Lalloo R, Laslett LL, 
Lathlean T, Leasher JL, Lee YY, Leigh J, Lim SS, Limb E, Lin JK, Lipnick M, Lipshultz

SE, Liu W, Loane M, Ohno SL, Lyons R, Ma J, Mabweijano J, MacIntyre MF, Malekzadeh R, Mallinger L, Manivannan S, Marcenes W, March L, Margolis DJ, Marks GB, Marks R, Matsumori A, Matzopoulos R, Mayosi BM, McAnulty JH, McDermott MM, McGill N, McGrath J, Medina-Mora ME, Meltzer M, Mensah GA, Merriman TR, Meyer AC, Miglioli V, Miller M, Miller TR, Mitchell PB, Mocumbi AO, Moffitt TE, Mokdad AA, Monasta L, Montico M, Moradi-Lakeh M, Moran A, Morawska L, Mori R, Murdoch ME, Mwaniki MK, Naidoo K, Nair MN, Naldi L, Narayan KM, Nelson PK, Nelson RG, Nevitt MC, Newton CR, Nolte S, Norman P, Norman R, O'Donnell M, O'Hanlon S, Olives C, Omer SB, Ortblad K, Osborne R, Ozgediz D, Page A, Pahari B, Pandian JD, Rivero AP, Patten SB, Pearce N, Padilla RP, Perez-Ruiz F, Perico N, Pesudovs K, Phillips D, Phillips MR, Pierce K, Pion S, Polanczyk GV, Polinder S, Pope CA 3rd, Popova S, Porrini E, Pourmalek F, Prince M, Pullan RL, Ramaiah KD, Ranganathan D, Razavi H, Regan M, Rehm JT, Rein DB, Remuzzi G, Richardson K, Rivara FP, Roberts T, Robinson C, De Leòn FR, Ronfani L, Room R, Rosenfeld LC, Rushton L, Sacco RL, Saha S, Sampson U, Sanchez-Riera L, Sanman E, Schwebel DC, Scott JG, Segui-Gomez M, Shahraz S, Shepard DS, Shin H, Shivakoti R, Singh D, Singh GM, Singh JA, Singleton J, Sleet DA, Sliwa K, Smith E, Smith JL, Stapelberg NJ, Steer A, Steiner T, Stolk WA, Stovner LJ, Sudfeld C, Syed S, Tamburlini G, Tavakkoli M, Taylor HR, Taylor JA, Taylor WJ, Thomas B, Thomson WM, Thurston GD, Tleyjeh IM, Tonelli M, Towbin JA, Truelsen T, Tsilimbaris MK, Ubeda C, Undurraga EA, van der Werf MJ, van Os J, Vavilala MS, Venketasubramanian N, Wang M, Wang W, Watt K, Weatherall DJ, Weinstock MA, Weintraub R, Weisskopf MG, Weissman MM, White RA, Whiteford H, Wiersma ST, Wilkinson JD, Williams HC, Williams SR, Witt E, Wolfe F, Woolf AD, Wulf S, Yeh PH, Zaidi AK, Zheng ZJ, Zonies D, Lopez AD, 
Murray CJ, AlMazroa MA, Memish ZA. 2012. Years lived with disability (YLDs) for 1160 sequelae of 289 diseases and injuries 1990-2010: a systematic analysis for the Global Burden of Disease Study 2010. The Lancet 380:2163-2196.

Warley A, Skepper JN. 2000. Long freeze-drying times are not necessary during the preparation of thin sections for X-ray microanalysis. J Microsc 198:116-123.

Whitford GM, Pashley DH, Reynolds KE. 1979. Fluoride tissue distribution: short-term kinetics. Am J Physiol 236:F141-F148.

Whitford GM, Pashley DH, Stringer GI. 1976. Fluoride renal clearance: a pH-dependent event. Am J Physiol 230:527-532.

Whitford GM, Sampaio FC, Pinto CS, Maria AG, Cardoso VE, Buzalaf MA. 2008.

Pharmacokinetics of ingested fluoride: lack of effect of chemical compound. Arch Oral Biol 53:1037-1041. 
Fig. 1. Effect of acute fluoride addition on transepithelial ion transport. (A) Representative $I_{s c}$ trace for a control epithelium, illustrating the effect of addition of amiloride (100 $\mu \mathrm{M})$. Periodic upward deflections represent the current responses to switching of the clamping voltage from zero to $2 \mathrm{mV}$ (5-s pulses every $30 \mathrm{~s}$ ). (B) Representative $\mathrm{I}_{\mathrm{sc}}$ trace showing the lack of effect of fluoride $(1 \mathrm{mM})$ on the current and on the inhibitory effect of amiloride (100 $\mu \mathrm{M}$ ). (C) Relationship between $\mathrm{I}_{\mathrm{sc}}$ and the concentration of fluoride added acutely. Bars show standard errors of the mean. (D) Relationship between $\mathrm{R}_{\mathrm{t}}$ and the concentration of fluoride added acutely. Bars show SEM.

Fig. 2. Effect of 96-h fluoride treatment on transepithelial ion transport. (A) Representative $\mathrm{I}_{\mathrm{sc}}$ trace for a control epithelium, illustrating the effect of addition of amiloride (100 $\left.\mu \mathrm{M}\right)$. (B) Representative $\mathrm{I}_{\mathrm{sc}}$ trace for an epithelium treated for $96 \mathrm{~h}$ with fluoride $(700 \mu \mathrm{M})$, illustrating the effect of addition of amiloride $(100 \mu \mathrm{M})$. (C) Relationship between $\mathrm{I}_{\mathrm{sc}}$ and fluoride concentration. Bars show standard errors of the mean. (D) Relationship between $\mathrm{R}_{\mathrm{t}}$ and fluoride concentration. Bars show SEM.

\footnotetext{
Fig. 3. Time-courses of the effects of fluoride on $I_{s c}(A)$ and $R_{t}(B)$. Data are shown for control epithelia (open symbols, dotted line) and for epithelia treated with $1 \mathrm{mM}$ fluoride. Bars show SEM.
} 
Fig. 4. Effect of fluoride on dome formation in epithelia grown on impermeable plastic supports. Arrows indicate domes. Scale bar, $100 \mu \mathrm{m}$.

Fig. 5. Effect of fluoride treatment on the sensitivity of transepithelial $\mathrm{Na}^{+}$transport to amiloride. Data are shown for control epithelia (open symbols, dotted line) and for epithelia treated for $96 \mathrm{~h}$ with $400 \mu \mathrm{M}$ fluoride (closed symbols, solid line). Bars show SEM.

Fig. 6. Effect of fluoride treatment on epithelial structure. (A) Representative scanning electron micrographs of the apical surface of a control epithelium (left) and an epithelium treated for $96 \mathrm{~h}$ with $1 \mathrm{mM}$ fluoride (right). Scale bars, $5 \mu \mathrm{M}$. (B) Representative transmission electron micrographs of sections through a control epithelium (left) and an epithelium treated for $96 \mathrm{~h}$ with $1 \mathrm{mM}$ fluoride (right). Arrows indicate tight junctions. Scale bars, $500 \mathrm{~nm}$.

Fig. 7. Effect of fluoride on tight junction integrity. Immunofluorescence images showing the distribution of ZO-1 in a control epithelium (A) and in an epithelium treated for $96 \mathrm{~h}$ with 1 $\mathrm{mM}$ fluoride (B). Arrows indicate ZO-1 staining that is not part of a complete polygon. Scale bar, $20 \mu \mathrm{m}$. 
Fig. 8. Sub-network generated by JActiveModules for the comparison between control group and group treated with $1 \mathrm{mM}$ fluoride for $24 \mathrm{~h}$. Red and green nodes indicate protein downregulation and up-regulation by fluoride. Blue and yellow nodes indicate proteins identified exclusively in control and fluoride-treated groups, respectively, while grey nodes indicate interacting proteins that were not identified in the present study. The protein-protein interaction networking was downloaded from PSICQUIC (Orchard, 2012), built in Cytoscape version 3.0.2 and constructed as proposed by Millan (2013).

Fig. 9. Sub-network generated by JActiveModules for the comparison between control group and group treated with $1 \mathrm{mM}$ fluoride for $96 \mathrm{~h}$. Red and green nodes indicate protein downregulation and up-regulation by fluoride. Blue nodes indicate proteins identified exclusively in control group, while grey nodes indicate proteins presenting interaction but that were not identified in the present study. Protein-protein interaction networking was carried out as in Fig. 8. 


\section{Figure 1}

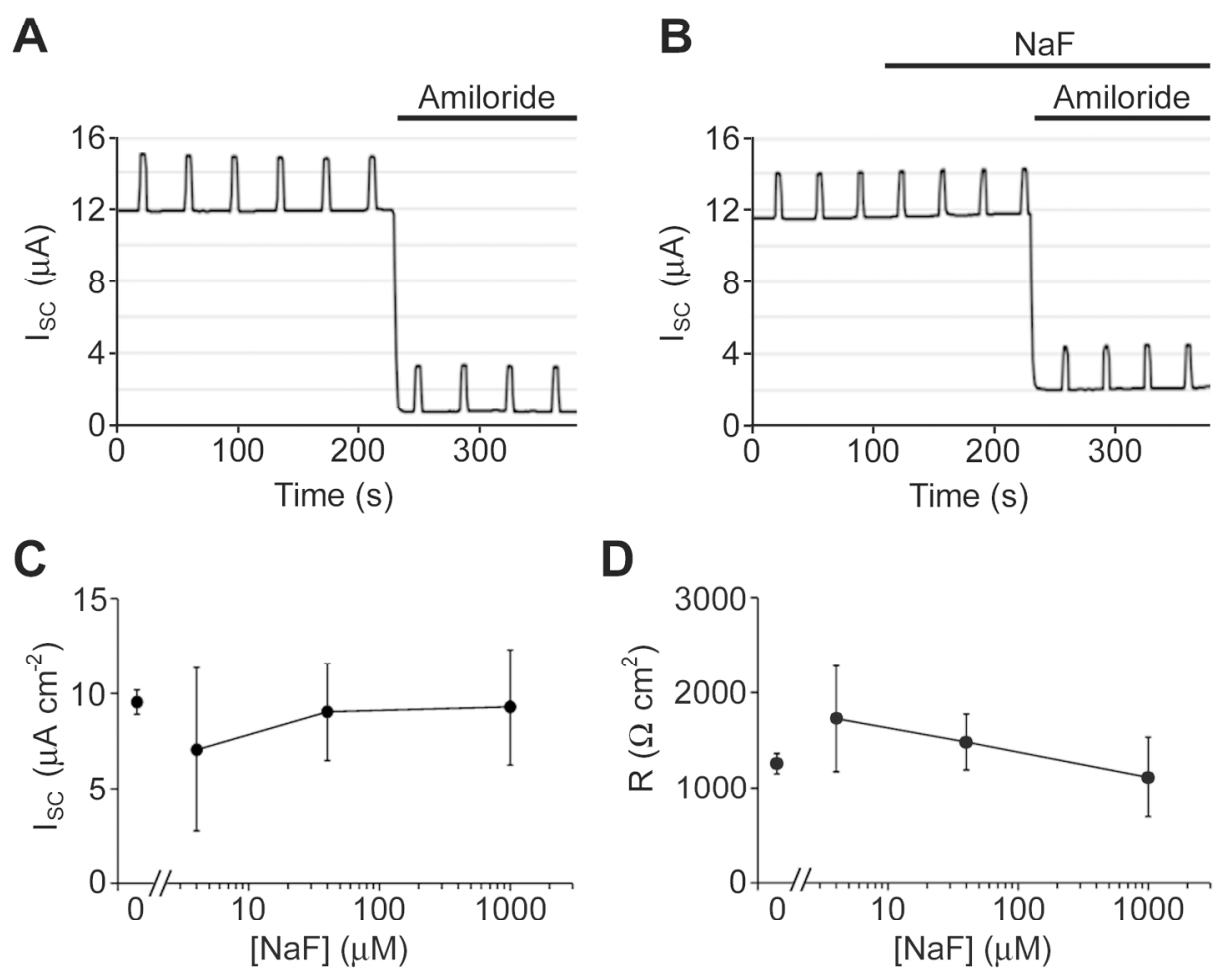

Figure 1.

$166 \times 147 \mathrm{~mm}(300 \times 300$ DPI)

John Wiley \& Sons 


\section{Figure 2}

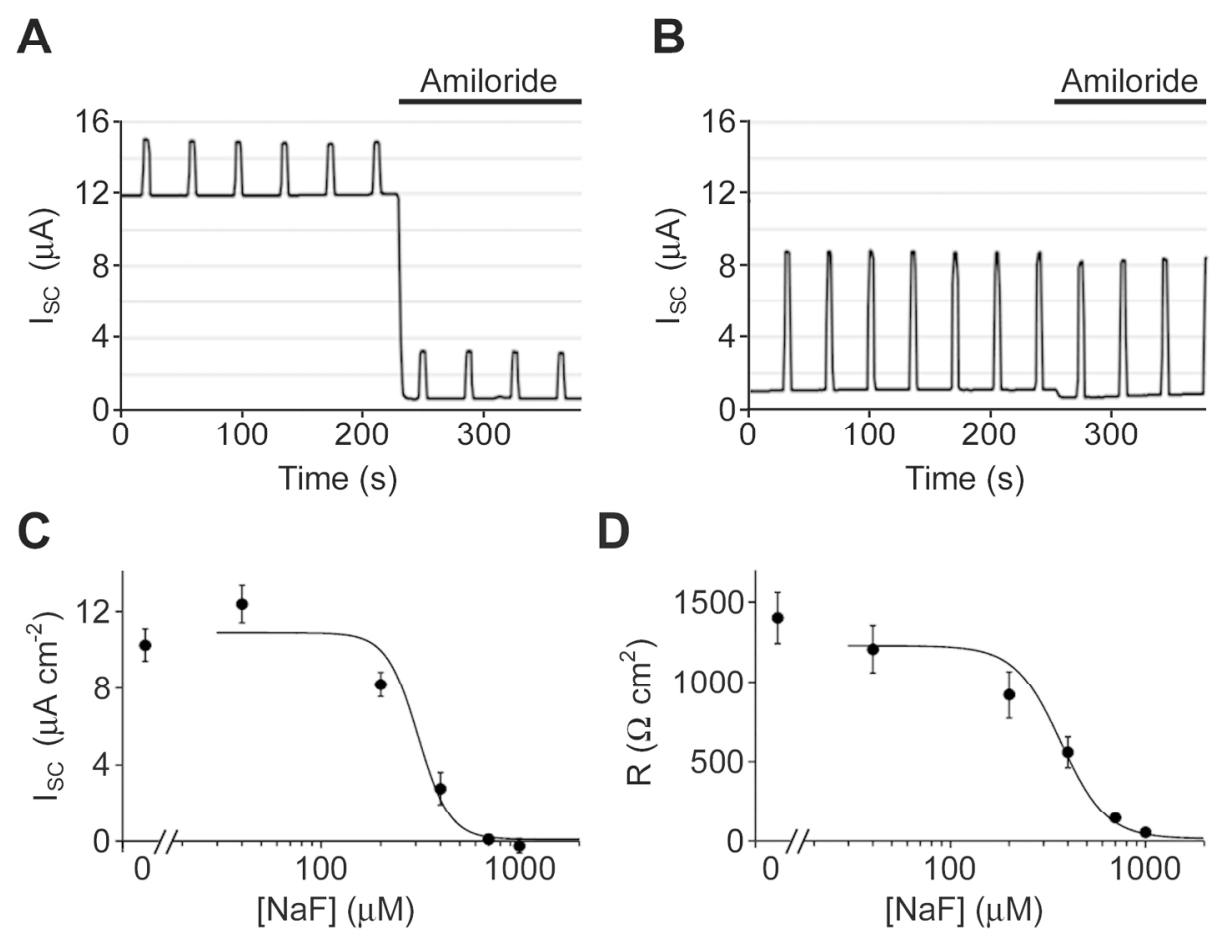

Figure 2

$166 \times 147 \mathrm{~mm}(300 \times 300 \mathrm{DPI})$ 


\section{Figure 3}

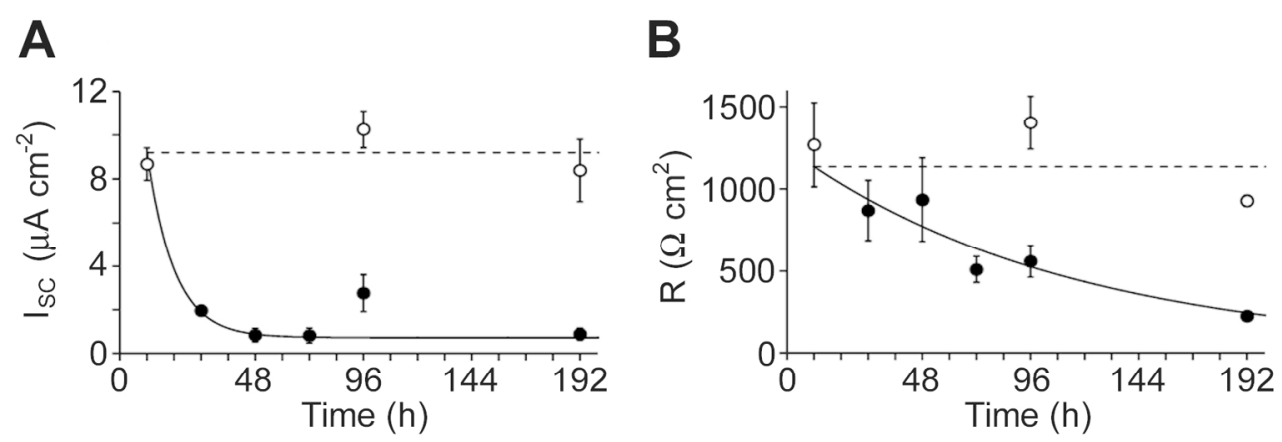

Figure 3

$159 \times 77 \mathrm{~mm}(300 \times 300 \mathrm{DPI})$ 


\section{Figure 4}

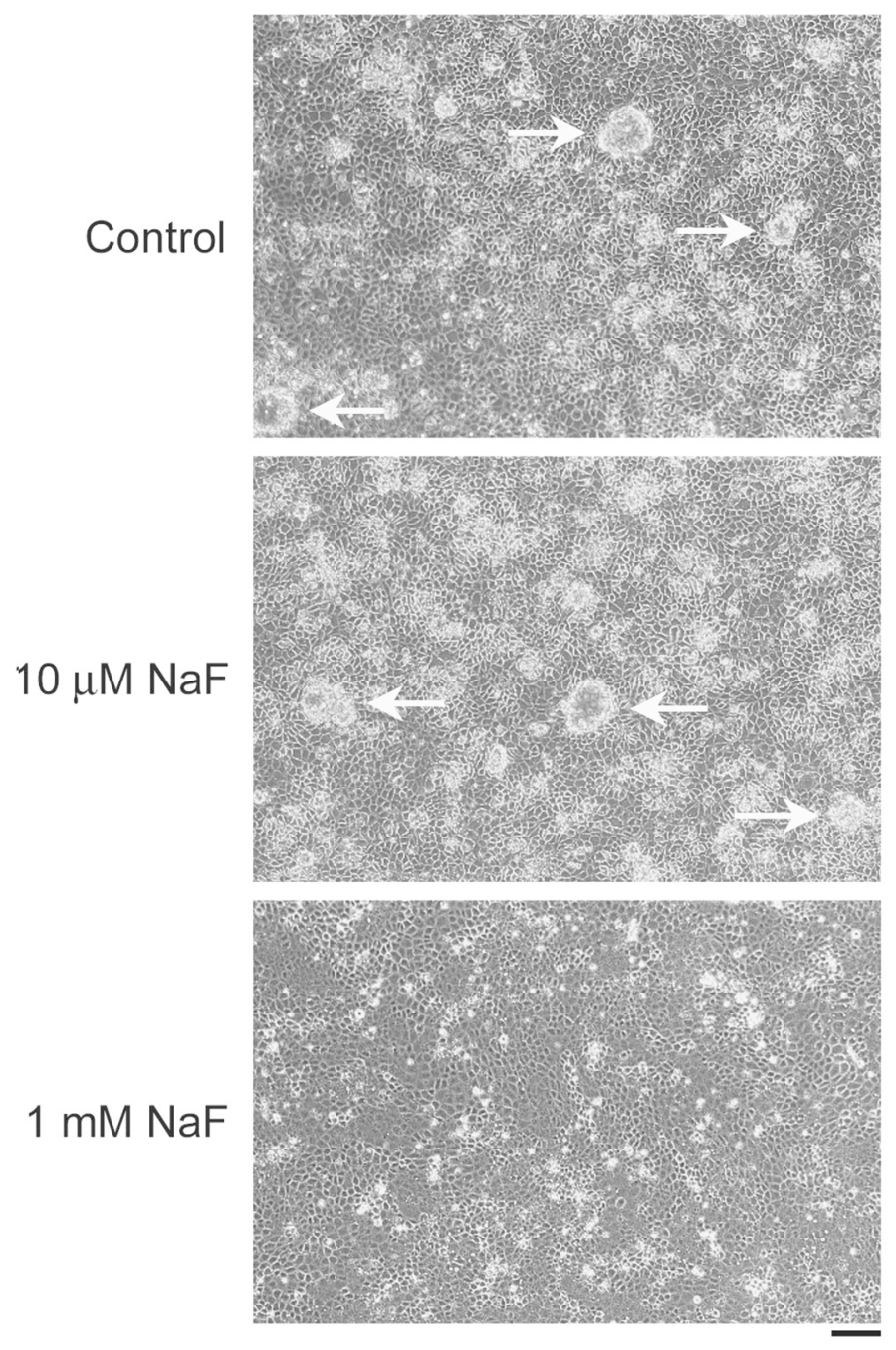

Figure 4

$105 \times 150 \mathrm{~mm}(300 \times 300$ DPI $)$ 


\section{Figure 5}

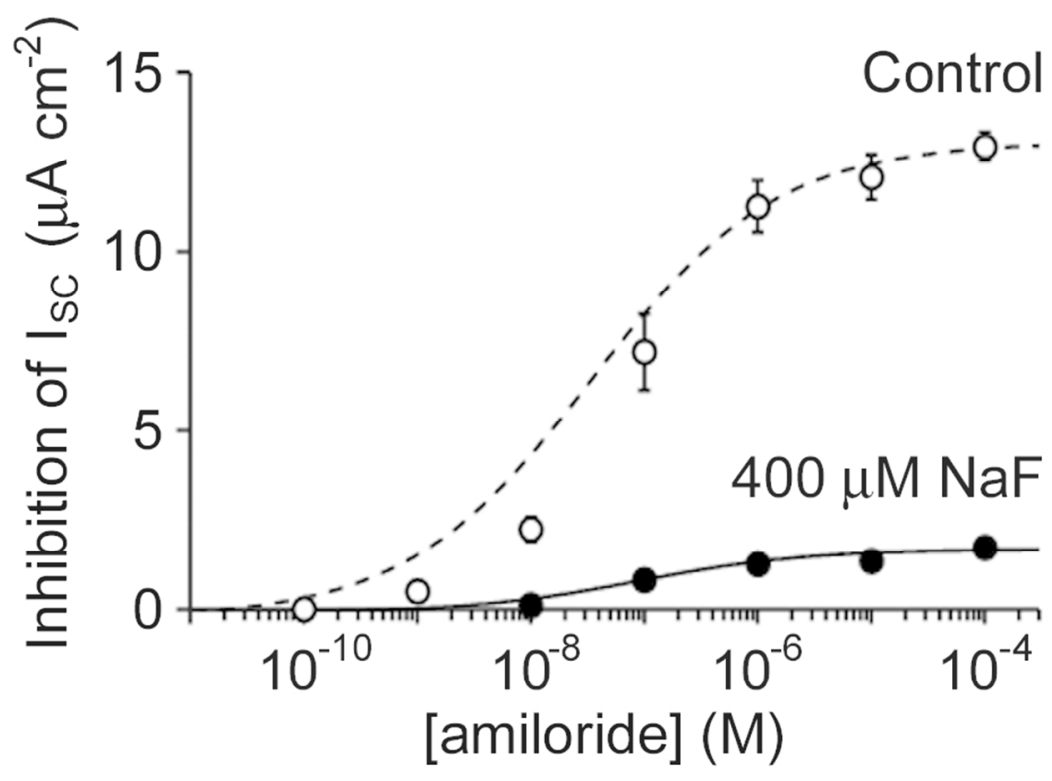

Figure 5

$97 \times 87 \mathrm{~mm}(300 \times 300$ DPI $)$ 


\section{Figure 6}

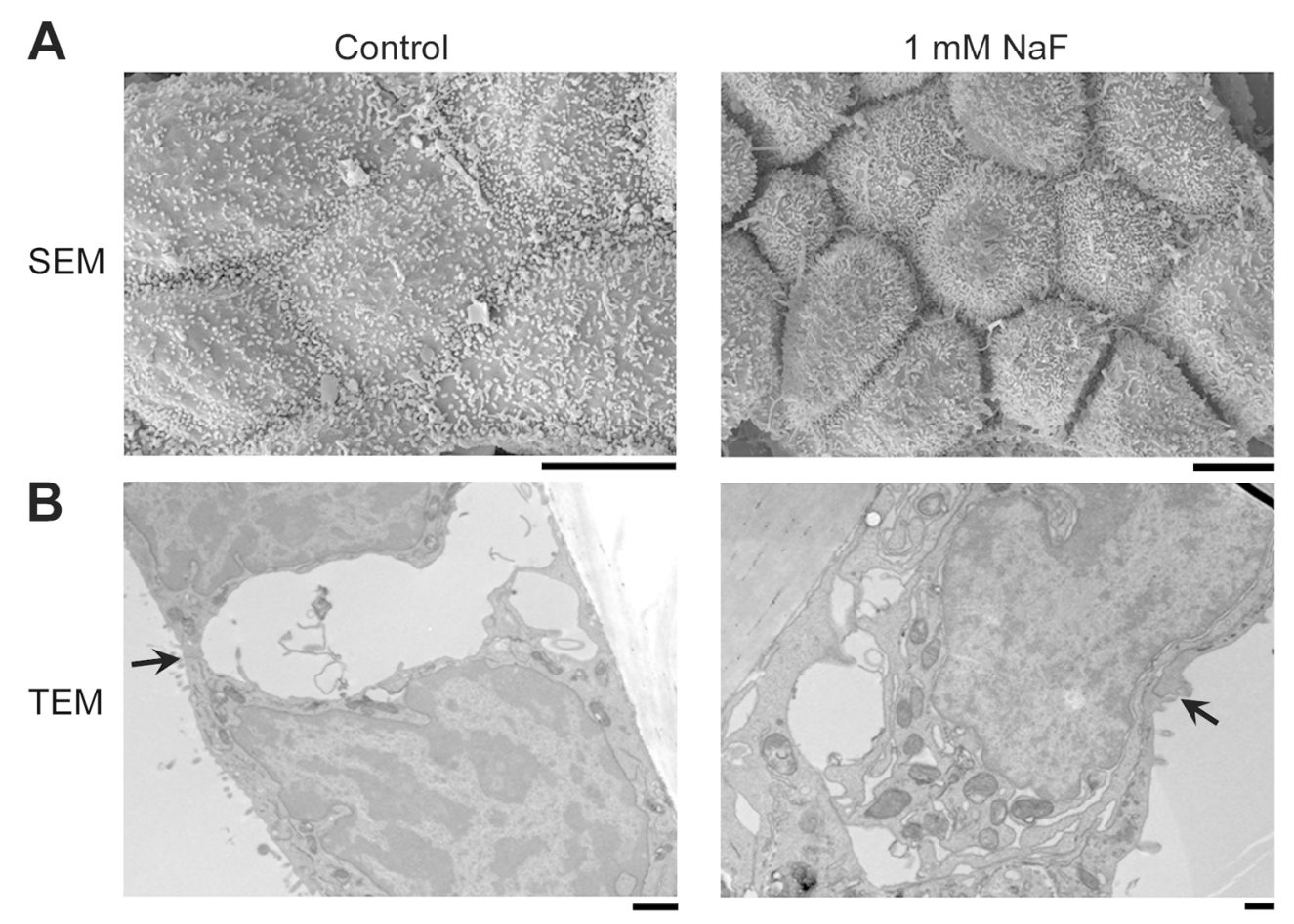

Figure 6

$150 \times 117 \mathrm{~mm}(300 \times 300$ DPI $)$ 
Figure 7

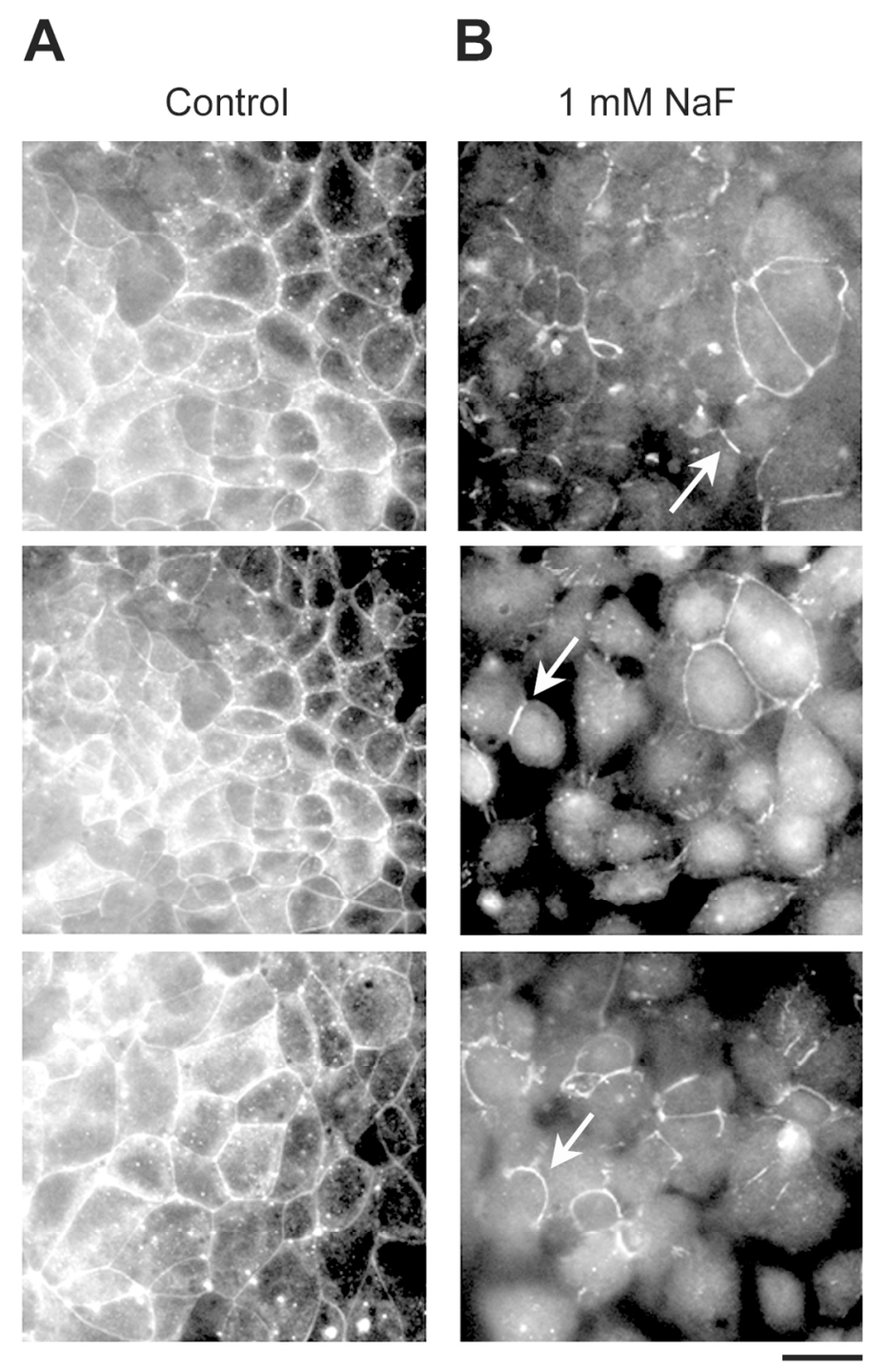

Figure 7

$104 \times 163 \mathrm{~mm}(300 \times 300$ DPI $)$

John Wiley \& Sons 
Figure 8

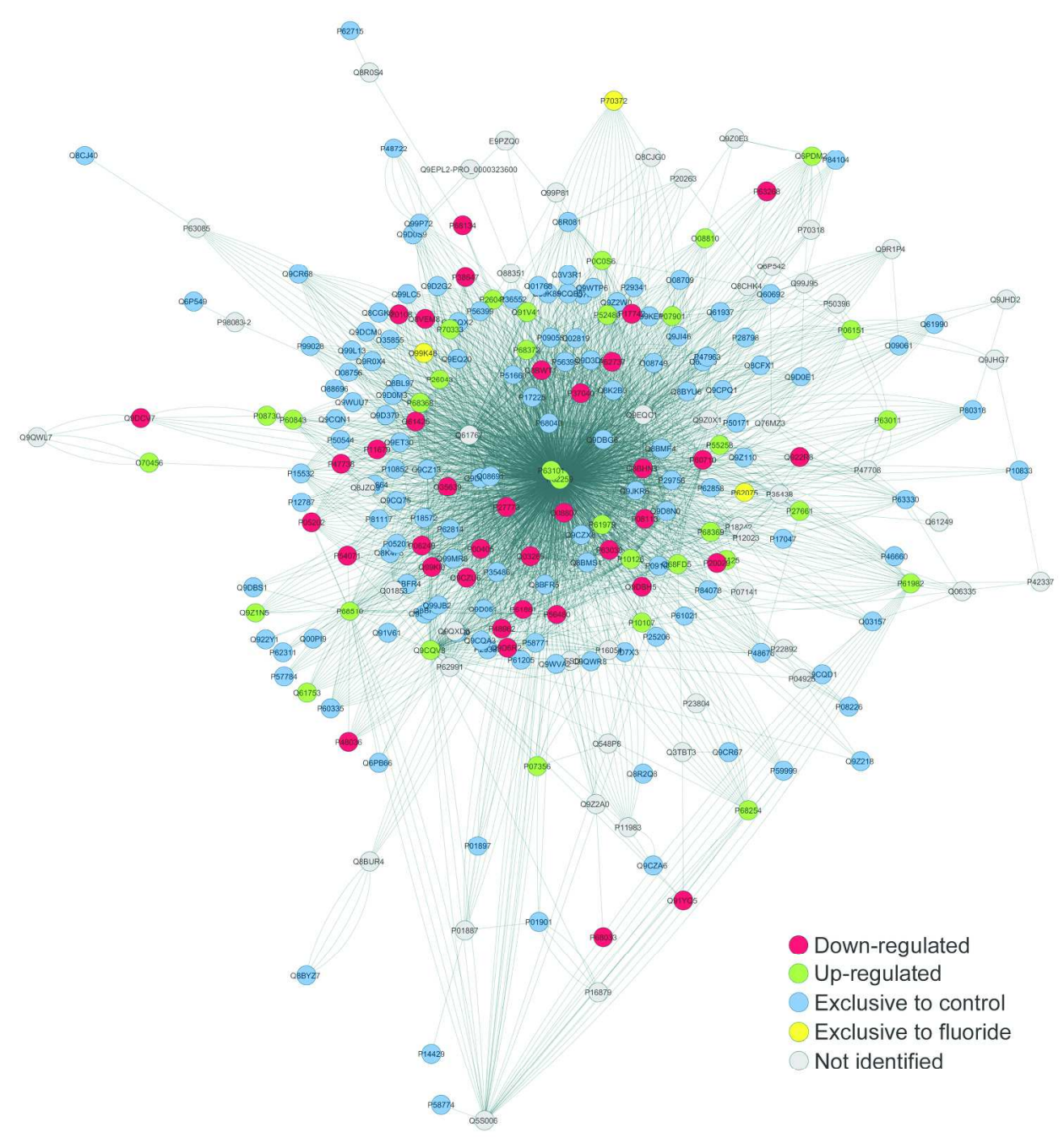

Figure 8

$209 \times 240 \mathrm{~mm}(300 \times 300 \mathrm{DPI})$

49

50

51

52

53

54

55

56

57

58

59

60 


\section{Figure 9}

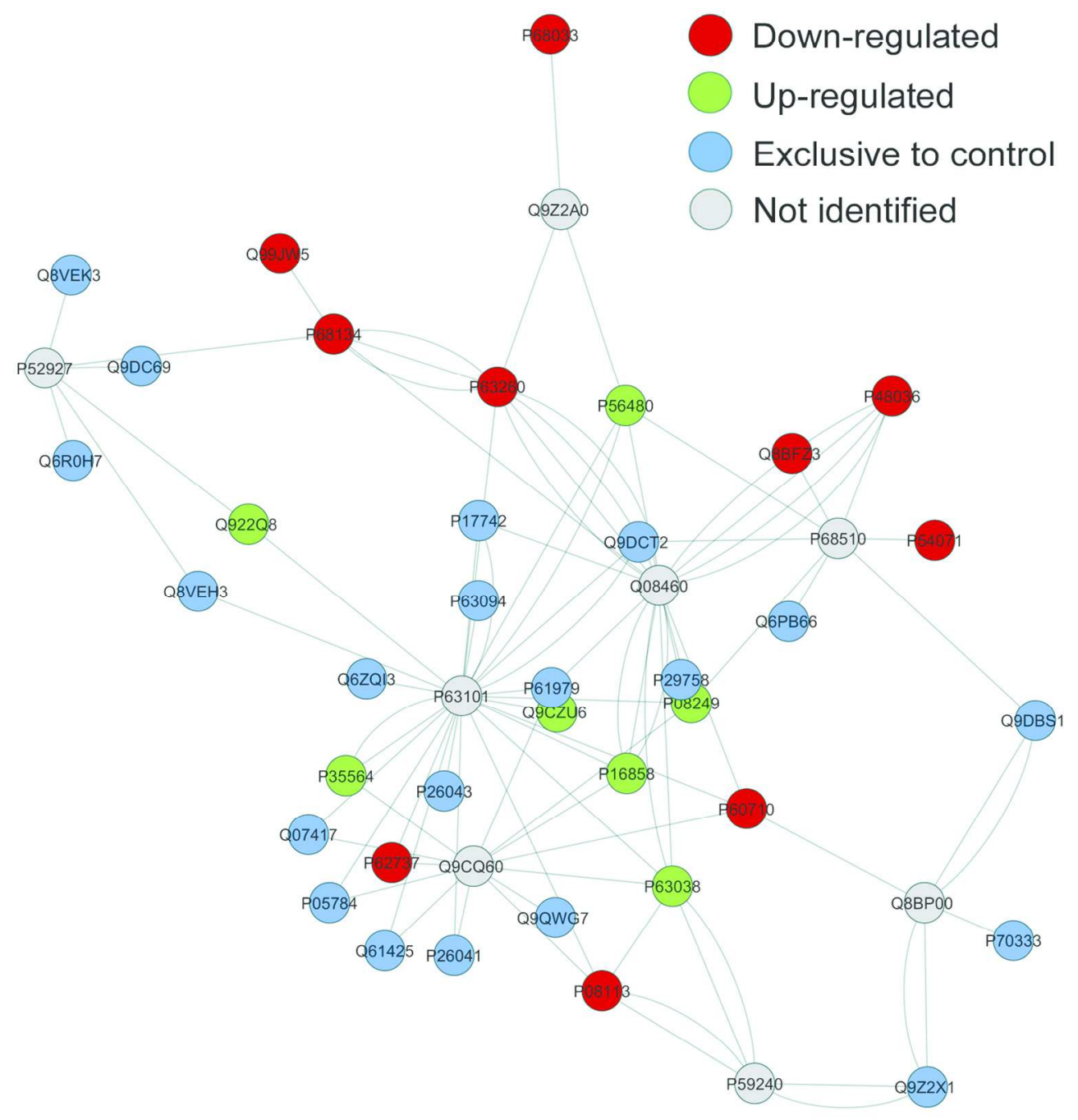

Figure 9

$128 \times 146 \mathrm{~mm}(300 \times 300 \mathrm{DPI})$ 